\title{
Perfusion parameters during cardiopulmonary bypass as a predictor of acute kidney injury after aortic valve replacement
}

\author{
Yeiwon Lee', Sue Hyun Kim', Ho Young Hwang ${ }^{2}$, Suk Ho Sohn², Jae Woong Choi ${ }^{2}$, Kyung Hwan Kim² \\ Departments of ${ }^{1}$ Critical Care and ${ }^{2}$ Thoracic and Cardiovascular Surgery, Seoul National University Hospital, Seoul National University College of Medicine, \\ Seoul, Korea
}

Background: Acute kidney injury (AKI) is a major complication after cardiac surgery and significantly affects postoperative mortality and morbidity. This study was conducted to evaluate the association between target pump flow to achieve adequate oxygen delivery $\left(\mathrm{DO}_{2}\right)$ and postoperative renal function after aortic valve replacement.

Methods: From January 2017 to May 2020, 281 patients (male:female, 160:121; mean age, $68 \pm 11$ years) who underwent aortic valve replacement were retrospectively reviewed. Target pump flow was calculated based on $\mathrm{DO}_{2}$ level of $280 \mathrm{~mL} / \mathrm{min} / \mathrm{m}^{2}$. The primary endpoint was postoperative renal dysfunction, defined as the ratio of postoperative peak creatinine level to preoperative value. The ratio of the lowest actual pump flow to the ideal target pump flow, other hemodynamic variables related with cardiopulmonary bypass, intraoperative transfusion, and preoperative characteristics were analyzed to identify factors associated with the primary endpoint using a multivariable linear regression model.

Results: Preoperative and peak postoperative creatinine levels were $0.94 \pm 0.33 \mathrm{mg} / \mathrm{dl}$ and $1.15 \pm 0.56 \mathrm{mg} / \mathrm{dl}$, respectively (ratio, $1.22 \pm 0.33$ ). The ideal target pump flow was $4.70 \pm 0.59$ $\mathrm{L} / \mathrm{min}$, whereas the lowest actual pump flow was $3.77 \pm 0.47 \mathrm{~L} / \mathrm{min}$ (ratio, $0.81 \pm 0.13$ ). The multivariable model showed that the ratio of the lowest pump flow to target pump flow ( $\beta \pm$ standard error, $-0.405 \pm 0.162, P=0.013$ ), as well as sex, stroke history, emergency operation, and transfusion of red blood cells were associated with the primary endpoint.

Conclusions: Low actual nadir pump flow compared to the ideal target pump flow based on $\mathrm{DO}_{2}$ is associated with the risk of AKI after aortic valve replacement.

Key Words: acute kidney injury; aortic valve replacement; oxygen delivery

\section{INTRODUCTION}

Acute kidney injury (AKI) is a common postoperative complication that occurs in $20 \%$ to $40 \%$ of cardiac surgical patients [1-3]. Postoperative AKI is associated with mortality after surgery, which increases up to $50 \%$ when renal replacement therapy is required [4]. In addition, even small decreases in glomerular filtration rates might be associated with increased postoperative mortality [5]. Previous studies demonstrated various risk factors associated with occurrence of AKI after cardiac surgery [3,6-8]. These include age, diabetes mellitus, pre-existing renal dysfunction, prolonged cardiopulmonary bypass (CPB) time, and use of adrenergic med-

\section{Original Article}

Received: January 18, 2021

Revised: March 19, 2021

Accepted: May 4, 2021

Corresponding author Sue Hyun Kim

Department of Critical Care, Seoul National University Hospital, 101 Daehak-ro, Jongno-gu, Seoul 03080, Korea

Tel: $+82-2-2072-2348$

Fax: +82-2-765-7117

E-mail: annesue01@gmail.com

Copyright $\odot 2021$ The Korean Society of Critical Care Medicine

This is an Open Access article distributed under the terms of Creative Attributions Non-Commercial License (https:// creativecommons.org/li-censes/by-nc/4.0/) which permits unrestricted noncommercial use, distribution, and reproduction in any medium, provided the original work is properly cited. 
ications [3,6-8].

In addition to well-known risk factors, recent studies [9-11] have demonstrated that nadir oxygen delivery $\left(\mathrm{DO}_{2}\right)$ during $\mathrm{CPB}$ is the best predictor of AKI after cardiac surgery. These observations have led to the concept of goal-directed perfusion, which is intended to maintain the $\mathrm{DO}_{2}$ level above the critical value during $\mathrm{CPB}$. CPB flow is one of the modifiable risk factors for AKI and has conventionally been largely based on monitoring of a formula based on the cardiac index multiplied by the body surface area of the patient. However, pump flow based solely on a cardiac index does not ensure satisfactory $\mathrm{DO}_{2}$ to the tissues, which can lead to metabolic acidosis, hyperlactatemia, and end-organ ischemia. However, high-level evidence of the association of goal-directed perfusion strategy and postoperative AKI remains lacking. Therefore, this study was conducted to evaluate the association between perfusion parameters during $\mathrm{CPB}$ and postoperative renal dysfunction after aortic valve replacement (AVR).

Table 1. Characteristics of the study patients

\begin{tabular}{|c|c|}
\hline Variable & Total $(n=281)$ \\
\hline Age (yr) & $68.0 \pm 11.5$ \\
\hline Male & $160(57)$ \\
\hline Body surface area $\left(\mathrm{m}^{2}\right)$ & $1.65 \pm 0.18$ \\
\hline Overweight (BMI > 25 kg/m²) & $110(39.1)$ \\
\hline \multicolumn{2}{|l|}{ Risk factor } \\
\hline Smoking & $79(28.1)$ \\
\hline Hypertension & $152(54.1)$ \\
\hline Diabetes mellitus & $79(28.1)$ \\
\hline Dyslipidemia & $116(41.3)$ \\
\hline History of stroke & $25(8.9)$ \\
\hline Chronic kidney disease (GFR <60 ml/min) & $47(16.7)$ \\
\hline Chronic obstructive pulmonary disease & $25(8.9)$ \\
\hline Peripheral vascular disease & $29(10.3)$ \\
\hline NYHA class $\geq 3$ & $49(17.4)$ \\
\hline Left ventricular dysfunction $(E F<0.50)$ & $45(16.0)$ \\
\hline Coronary artery disease & 78 (27.8) \\
\hline EuroSCORE II & $2.2 \pm 2.1$ \\
\hline STS score & $2.2 \pm 2.4$ \\
\hline Atrial fibrillation & $17(6.0)$ \\
\hline Emergent operation & $3(1.1)$ \\
\hline Infective endocarditis & $10(3.6)$ \\
\hline
\end{tabular}

Values are presented as mean \pm standard deviation or number $(\%)$. BMI: body mass index; GFR: glomerular filtration rate; NYHA: New York Heart Association; EF: ejection fraction; EuroSCORE: European System for Cardiac Operative Risk Evaluation; STS: Society of Thoracic Surgeons.

\section{KEY MESSAGES}

- The actual lowest pump flow compared to the target pump flow based on oxygen delivery $\left(\mathrm{DO}_{2}\right)$ might be a predictor of postoperative acute kidney injury after cardiac surgery.

- Female sex, stroke history, emergency operation, and transfusion of red blood cells were significant risk factors of postoperative acute kidney injury after cardiac surgery.

\section{MATERIALS AND METHODS}

\section{Patient Characteristics}

The study protocol was reviewed by the Institutional Review Board of Seoul National University Hospital and approved as a minimal risk retrospective study (IRB No. H-2009-158-1159) that did not require individual consent based on the institutional guidelines for waiving consent. A total of 434 patients who underwent AVR between January 2017 and May 2020, at our institution was retrospectively screened. Patients who underwent concomitant valve surgery other than AVR $(n=40)$, aortic surgery under total circulatory arrest $(n=68)$, arrhythmia surgery $(\mathrm{n}=32)$, and those with preoperative end-stage renal disease on dialysis $(n=21)$ were excluded. A final total of 281 patients was enrolled in the present study. The mean age at operation was $68 \pm 11$ years, and 160 patients (56.9\%) were male. The European System for Cardiac Operative Risk Evaluation (EuroSCORE) II and Society of Thoracic Surgeons (STS) score were $2.2 \pm 2.1$ and $2.2 \pm 2.4$, respectively. Hypertension $(\mathrm{n}=152,54.1 \%)$, dyslipidemia $(\mathrm{n}=116,41.3 \%)$, diabetes $(\mathrm{n}=79$, $28.1 \%)$, and coronary artery disease $(n=78,27.8 \%)$ were the most common comorbidities (Table 1).

Table 2. Operative data of the study patients

\begin{tabular}{lc}
\hline Variable & Total $(n=281)$ \\
\hline Mechanical:bioprosthesis & $66: 215$ \\
CPB time (min) & $147.4 \pm 51.6$ \\
ACC time (min) & $92.2 \pm 32.2$ \\
Concomitant procedure & \\
CABG & $35(12.5)$ \\
PFO closure & $12(4.3)$ \\
\hline
\end{tabular}

Values are presented as mean \pm standard deviation or number (\%). CPB: cardiopulmonary bypass; ACC: aortic cross clamp; CABG: coronary artery bypass grafting; PFO: patent foramen ovale. 


\section{Surgical Procedures}

All operations were performed through median sternotomy and aorto-bicaval cannulation under moderate hypothermia $\left(30^{\circ} \mathrm{C}-32^{\circ} \mathrm{C}\right)$. Concomitant procedures comprised coronary artery bypass grafting $(\mathrm{n}=35)$ and closure of patent foramen ovale $(\mathrm{n}=12)$. The mean CPB and aortic cross-clamp times were 147.4 \pm 51.6 and $92.2 \pm 32.2$ minutes, respectively (Table 2 ).

\section{Evaluation of Clinical Outcomes}

The target pump flow was calculated based on $\mathrm{DO}_{2}$ level of $280 \mathrm{ml} / \mathrm{min} / \mathrm{m}^{2}$ and the following equation: $\mathrm{DO}_{2}=$ pump flow $\times(\mathrm{Hb}$ concentration $\times \mathrm{Hb}$ saturation $\times 1.36)+\left(0.003 \times \mathrm{PaO}_{2}\right)$, where $\mathrm{Hb}$, hemoglobin; $\mathrm{PaO}_{2}$, arterial oxygen pressure [12]. Early mortality was defined as any death within 30 days or during the same hospitalization. Postoperative atrial fibrillation was defined as a new onset or any short run of atrial fibrillation. Low cardiac output syndrome (LCOS) was defined as a cardiac index $<2.0 \mathrm{~L} / \mathrm{min} / \mathrm{m}^{2}$ or a systolic arterial pressure $<90 \mathrm{~mm} \mathrm{Hg}$ for which the patient required mechanical assistance or high inotropic support such as dopamine or dobutamine in quantities $>5 \mu \mathrm{g} / \mathrm{kg} / \mathrm{min}$. Postoperative respiratory complications included pneumonia or prolonged ventilator support for more than 48 hours.

\section{Statistical Analysis}

The primary endpoint was postoperative renal dysfunction, defined as the ratio of the postoperative peak creatinine level to the preoperative value. The statistical analyses were performed using IBM SPSS ver. 23.0 (IBM Corp., Armonk, NY, USA). Continuous and dichotomous variables are expressed as the mean \pm standard deviation or median with interquartile range (IQR) and the number with the proportion, respectively. A paired t-test was performed to compare differences be-

Table 3. Early clinical outcomes

\begin{tabular}{lc}
\hline Variable & Total $(n=281)$ \\
\hline Early mortality & $7(2.5)$ \\
Complication & \\
New onset atrial fibrillation & $102(36.3)$ \\
Respiratory complications & $24(8.6)$ \\
Low cardiac output syndrome & $12(4.3)$ \\
Stroke & $5(1.8)$ \\
Complete atrioventricular block & $3(1.1)$ \\
Bleeding reoperation & $3(1.1)$ \\
Mediastinitis & $1(0.4)$ \\
\hline
\end{tabular}

Values are presented as number (\%). tween preoperative creatinine levels and postoperative peak creatinine levels.

The ratio of the actual pump flow to the target pump flow based on the $\mathrm{DO}_{2}$ and the presence of other perfusion parameters during CPB such as lowest temperature, mean arterial pressure, hematocrit levels, $\mathrm{PaO}_{2}$, intraoperative red blood cells (RBCs) transfusion, and preoperative characteristics were analyzed to identify factors associated with the primary endpoint. Univariate and multivariable analyses were performed using linear regression models. Variables with a P-value $<0.05$ in univariate analyses were entered into a multivariable model. Multi-collinearity was controlled using backward stepwise selection. The results of the multivariable analysis are expressed as $P$-value, beta coefficient ( $\beta$ ), and standard error (SE). A Pvalue $<0.05$ was considered statistically significant.

\section{RESULTS}

\section{Early Clinical Outcomes}

The early mortality rate was $2.5 \%$ ( 7 of 281 patients). Postoperative complications included respiratory complications ( $\mathrm{n}=$ $24,8.6 \%), \operatorname{LCOS}(\mathrm{n}=12,4.3 \%)$, stroke $(\mathrm{n}=5,1.8 \%)$, and bleeding reoperation $(\mathrm{n}=3,1.1 \%)$ (Table 3$)$.

\section{CPB Variables}

The lowest temperature and the lowest mean arterial pressure during $\mathrm{CPB}$ were $30.4^{\circ} \mathrm{C} \pm 2.4^{\circ} \mathrm{C}$ and $58.9 \pm 8.8 \mathrm{~mm} \mathrm{Hg}$, respectively. The lowest hematocrit level was $21.5 \% \pm 3.0 \%$, and the median number of RBCs transfused during CPB was 0.5 (IQR, 0-1.0). Mean $\mathrm{PaO}_{2}$ was $338.4 \pm 45.0 \mathrm{~mm} \mathrm{Hg}$. Based on the assumed target $\mathrm{DO}_{2}$ index of $280 \mathrm{ml} / \mathrm{min} / \mathrm{m}^{2}$, the ideal target pump flow was $4.7 \pm 0.6 \mathrm{~L} / \mathrm{min}$, and the lowest actual pump

Table 4. Cardiopulmonary bypass variables

\begin{tabular}{lc}
\hline Variable & Total $(\mathrm{n}=281)$ \\
\hline Lowest temperature $\left({ }^{\circ} \mathrm{C}\right)$ & $30.4 \pm 2.4$ \\
Lowest mean arterial pressure $(\mathrm{mm} \mathrm{Hg})$ & $58.9 \pm 8.8$ \\
Lowest hematocrit $(\%)$ & $21.5 \pm 3.0$ \\
Transfused $\mathrm{RBC}($ pack $)$ & $0.5(0-1.0)$ \\
$\mathrm{PaO}_{2}(\mathrm{~mm} \mathrm{Hg})$ & $338.4 \pm 45.0$ \\
Ideal target pump flow $(\mathrm{L} / \mathrm{min})$ & $4.70 \pm 0.59$ \\
Lowest actual pump flow $(\mathrm{L} / \mathrm{min})$ & $3.77 \pm 0.47$ \\
Ratio of the lowest actual pump flow & $0.81 \pm 0.13$ \\
to the ideal target pump flow & \\
\hline
\end{tabular}

Values are presented as mean \pm standard deviation or median (interquartile range).

RBC: red blood cell; $\mathrm{PaO}_{2}$ : arterial oxygen pressure. 
flow was $3.8 \pm 0.5 \mathrm{~L} / \mathrm{min}$ during $\mathrm{CPB}$. The ratio of the lowest actual pump flow to the ideal target pump flow was $0.81 \pm 0.13$ (Table 4).

\section{Changes in Creatinine Level after Surgery}

Creatinine increased from a preoperative level of $0.94 \pm 0.33$ $\mathrm{mg} / \mathrm{dl}$ to a postoperative peak level of $1.15 \pm 0.56 \mathrm{mg} / \mathrm{dl}(\mathrm{P}<0.001)$. The postoperative creatinine level was highest at postoperative day 1 (IQR, 1-2). The ratio of postoperative peak creatinine level to preoperative creatinine level was $1.22 \pm 0.33$ (Table 5).

\section{Risk Factor Analyses for the Primary Endpoint}

Univariate analyses demonstrated that the ratio of the actual pump flow to the ideal target pump flow $(\mathrm{P}=0.009)$, age, sex, stroke history, EuroScore II, emergency status, hematocrit level, and RBC transfusion during CPB were significant factors associated with the primary endpoint. In the multivariable model, the ratio of the lowest pump flow to the maximum target pump flow $(\beta \pm S E,-0.405 \pm 0.162 ; \mathrm{P}=0.013)$, sex (reference: female; $0.193 \pm 0.045, \mathrm{P}<0.001$ ), stroke history (0.197 $\pm 0.066, P=0.003)$, emergency $(0.364 \pm 0.181, P=0.045)$, and RBC transfusion $(0.099 \pm 0.033, \mathrm{P}=0.003)$ were associated with the primary endpoint for postoperative renal dysfunction (Table 6).

Table 5. Changes in renal function

\begin{tabular}{lc}
\hline Variable & Value \\
\hline Preoperative creatinine level $(\mathrm{mg} / \mathrm{dl})$ & $0.94 \pm 0.33$ \\
Postoperative peak creatinine level $(\mathrm{mg} / \mathrm{dl})$ & $1.15 \pm 0.56$ \\
Postoperative day at highest creatinine level & $1(1-2)$ \\
Ratio of postoperative to preoperative creatinine level & $1.22 \pm 0.33$ \\
\hline
\end{tabular}

Values are presented as mean \pm standard deviation or median (interquartile range).

Table 6. Risk factor analysis for changes in creatinine level after surgery

\begin{tabular}{|c|c|c|c|}
\hline \multirow{2}{*}{ Variable } & \multirow{2}{*}{$\begin{array}{c}\text { Univariate analysis } \\
\text { P-value }\end{array}$} & \multicolumn{2}{|c|}{ Multivariable analysis } \\
\hline & & $\beta \pm S E$ & P-value \\
\hline Sex (reference: female) & 0.034 & $0.193 \pm 0.045$ & $<0.001$ \\
\hline History of stroke & 0.002 & $0.197 \pm 0.066$ & 0.003 \\
\hline Emergency & 0.007 & $0.364 \pm 0.181$ & 0.045 \\
\hline Transfusion of red blood cells & 0.009 & $0.099 \pm 0.033$ & 0.003 \\
\hline Ratio of lowest actual pump flow to target pump flow & 0.009 & $-0.405 \pm 0.162$ & 0.013 \\
\hline
\end{tabular}

Values are presented as mean \pm standard deviation. Variables in Tables 1, 2, 4, and 5 were included in the analysis, and factors that were significant in the multivariable models are shown.

SE: standard error. 
own experiences. Recently, $\mathrm{DO}_{2}$ has been suggested as an important modifiable parameter that prevents postoperative AKI. Two important variables for perfusion, i.e., hematocrit values and $\mathrm{CPB}$ pump flow rates, are incorporated into a single calculation of $\mathrm{DO}_{2}$. A previous study [9], in a retrospective series, found a "critical" $\mathrm{DO}_{2}$ threshold of $272 \mathrm{~mL} / \mathrm{min} / \mathrm{m}^{2}$. When $\mathrm{DO}_{2}$ level falls below the critical value of $260-270 \mathrm{~mL} /$ $\mathrm{min} / \mathrm{m}^{2}$, organ deoxygenation can be triggered with subsequent tissue acidosis, causing impaired postoperative renal function. Another study [11] investigated the role of potentially modifiable factors related to CPB management in determining postoperative AKI. The study results demonstrated that low $\mathrm{DO}_{2}$ level during CPB is independently associated with postoperative AKI. They found that a nadir $\mathrm{DO}_{2}$ less than $262 \mathrm{~mL} / \mathrm{min} / \mathrm{m}^{2}$ was independently associated with development of postoperative AKI.

In the present study, based on the assumed target $\mathrm{DO}_{2}$ level of $280 \mathrm{~mL} / \mathrm{min} / \mathrm{m}^{2}$, the ideal target pump flow was assumed to be $4.7 \pm 0.6 \mathrm{~L} / \mathrm{min}$ during $\mathrm{CPB}$. Among the various CPB parameters, not the absolute value but the ratio of the nadir pump flow to the ideal target flow based on the $\mathrm{DO}_{2}$ was associated with risk of AKI. In addition, the multivariable model demonstrated that not the nadir hematocrit level during CPB but transfusion was associated with AKI. The relationship between transfusion of RBCs and AKI development has long been reported in surgical literature [2,34]. However, the need for blood transfusion might be just an indicator of increased blood loss and a hypotensive or ischemic state, which is a main pathogenic mechanism of AKI. Therefore, further study is needed to clarify the impact of low hematocrit levels vs. RBC transfusion on clinical outcomes after cardiac surgery.

The present study has limitations that should be recognized. First, this was a retrospective observational study performed in a single institution. Therefore, our models must be validated at multiple centers for broader applicability. Second, the effects of unknown or unmeasured confounders associated with postoperative AKI cannot be ruled out. Finally, the number of enrolled patients in this study was relatively small. In conclusion, low actual nadir pump flow during CPB compared to the ideal target pump flow based on the $\mathrm{DO}_{2}$ is associated with risk of AKI after AVR.

\section{CONFLICT OF INTEREST}

No potential conflict of interest relevant to this article was reported.

\section{ORCID}

Yeiwon Lee

https://orcid.org/0000-0003-3342-1381

Sue Hyun Kim

https://orcid.org/0000-0002-7414-5232

Ho Young Hwang

https://orcid.org/0000-0002-8935-8118

Suk Ho Sohn

https://orcid.org/0000-0001-7391-3415

Jae Woong Choi

https://orcid.org/0000-0002-0921-756X

Kyung Hwan Kim

\section{AUTHOR CONTRIBUTIONS}

Conceptualization: SHK, HYH. Data curation: SHK, HYH. Formal analysis: SHK, HYH. Methodology: SHK, HYH. Project administration: HYH, SHS, JWC, KHK. Visualization: SHK, HYH. Writing-original draft: YL, SHK, HYH. Writing-review \& editing: all authors.

\section{REFERENCES}

1. Vives M, Hernandez A, Parramon F, Estanyol N, Pardina B, Muñoz A, et al. Acute kidney injury after cardiac surgery: prevalence, impact and management challenges. Int J Nephrol Renovasc Dis 2019;12:153-66.

2. Karkouti K, Wijeysundera DN, Yau TM, Callum JL, Cheng DC, Crowther $\mathrm{M}$, et al. Acute kidney injury after cardiac surgery: focus on modifiable risk factors. Circulation 2009;119:495-502.

3. Huen SC, Parikh CR. Predicting acute kidney injury after cardiac surgery: a systematic review. Ann Thorac Surg 2012;93: 337-47.

4. Provenchère S, Plantefève G, Hufnagel G, Vicaut E, De Vaumas C, Lecharny JB, et al. Renal dysfunction after cardiac surgery with normothermic cardiopulmonary bypass: incidence, risk factors, and effect on clinical outcome. Anesth Analg 2003; 96:1258-64.

5. Elmistekawy E, McDonald B, Hudson C, Ruel M, Mesana T, Chan V, et al. Clinical impact of mild acute kidney injury after cardiac surgery. Ann Thorac Surg 2014;98:815-22.

6. Sirvinskas E, Andrejaitiene J, Raliene L, Nasvytis L, Karbonskiene A, Pilvinis V, et al. Cardiopulmonary bypass management and acute renal failure: risk factors and prognosis. Perfusion 2008;23:323-7.

7. Tuttle KR, Worrall NK, Dahlstrom LR, Nandagopal R, Kausz AT, Davis CL. Predictors of ARF after cardiac surgical procedures. Am J Kidney Dis 2003;41:76-83.

8. Bastin AJ, Ostermann M, Slack AJ, Diller GP, Finney SJ, Evans TW. Acute kidney injury after cardiac surgery according to Risk/Injury/Failure/Loss/End-stage, Acute Kidney Injury 
Network, and Kidney Disease: Improving Global Outcomes classifications. J Crit Care 2013;28:389-96.

9. Ranucci M, Romitti F, Isgrò G, Cotza M, Brozzi S, Boncilli A, et al. Oxygen delivery during cardiopulmonary bypass and acute renal failure after coronary operations. Ann Thorac Surg 2005; 80:2213-20.

10. Magruder JT, Dungan SP, Grimm JC, Harness HL, Wierschke C, Castillejo S, et al. Nadir oxygen delivery on bypass and hypotension increase acute kidney injury risk after cardiac operations. Ann Thorac Surg 2015;100:1697-703.

11. de Somer F, Mulholland JW, Bryan MR, Aloisio T, Van Nooten GJ, Ranucci M. O2 delivery and CO2 production during cardiopulmonary bypass as determinants of acute kidney injury: time for a goal-directed perfusion management? Crit Care 2011;15:R192.

12. Murphy GS, Hessel EA 2nd, Groom RC. Optimal perfusion during cardiopulmonary bypass: an evidence-based approach. Anesth Analg 2009;108:1394-417.

13. Brown JR, Cochran RP, MacKenzie TA, Furnary AP, Kunzelman KS, Ross CS, et al. Long-term survival after cardiac surgery is predicted by estimated glomerular filtration rate. Ann Thorac Surg 2008;86:4-11.

14. Hobson CE, Yavas S, Segal MS, Schold JD, Tribble CG, Layon AJ, et al. Acute kidney injury is associated with increased longterm mortality after cardiothoracic surgery. Circulation 2009; 119:2444-53.

15. Liotta M, Olsson D, Sartipy U, Holzmann MJ. Minimal changes in postoperative creatinine values and early and late mortality and cardiovascular events after coronary artery bypass grafting. Am J Cardiol 2014;113:70-5.

16. Tolpin DA, Collard CD, Lee VV, Virani SS, Allison PM, Elayda MA, et al. Subclinical changes in serum creatinine and mortality after coronary artery bypass grafting. J Thorac Cardiovasc Surg 2012;143:682-8.

17. Lassnigg A, Schmidlin D, Mouhieddine M, Bachmann LM, Druml W, Bauer P, et al. Minimal changes of serum creatinine predict prognosis in patients after cardiothoracic surgery: a prospective cohort study. J Am Soc Nephrol 2004;15:1597-605.

18. Englberger L, Suri RM, Li Z, Casey ET, Daly RC, Dearani JA, et al. Clinical accuracy of RIFLE and Acute Kidney Injury Network (AKIN) criteria for acute kidney injury in patients undergoing cardiac surgery. Crit Care 2011;15:R16.

19. Thakar CV, Worley S, Arrigain S, Yared JP, Paganini EP. Influence of renal dysfunction on mortality after cardiac surgery: modifying effect of preoperative renal function. Kidney Int 2005;67:1112-9.

20. Rosner MH, Okusa MD. Acute kidney injury associated with cardiac surgery. Clin J Am Soc Nephrol 2006;1:19-32.

21. Wijeysundera DN, Karkouti K, Dupuis JY, Rao V, Chan CT, Granton JT, et al. Derivation and validation of a simplified predictive index for renal replacement therapy after cardiac surgery. JAMA 2007;297:1801-9.

22. Palomba H, de Castro I, Neto AL, Lage S, Yu L. Acute kidney injury prediction following elective cardiac surgery: AKICS Score. Kidney Int 2007;72:624-31.

23. Mehta RH, Grab JD, O'Brien SM, Bridges CR, Gammie JS, Haan $\mathrm{CK}$, et al. Bedside tool for predicting the risk of postoperative dialysis in patients undergoing cardiac surgery. Circulation 2006;114:2208-16.

24. Thakar CV, Arrigain S, Worley S, Yared JP, Paganini EP. A clinical score to predict acute renal failure after cardiac surgery. J Am Soc Nephrol 2005;16:162-8.

25. Grayson AD, Khater M, Jackson M, Fox MA. Valvular heart operation is an independent risk factor for acute renal failure. Ann Thorac Surg 2003;75:1829-35.

26. Eriksen BO, Hoff KR, Solberg S. Prediction of acute renal failure after cardiac surgery: retrospective cross-validation of a clinical algorithm. Nephrol Dial Transplant 2003;18:77-81.

27. Janssen DP, Noyez L, van Druten JA, Skotnicki SH, Lacquet LK. Predictors of nephrological morbidity after coronary artery bypass surgery. Cardiovasc Surg 2002;10:222-7.

28. Mangano CM, Diamondstone LS, Ramsay JG, Aggarwal A, Herskowitz A, Mangano DT. Renal dysfunction after myocardial revascularization: risk factors, adverse outcomes, and hospital resource utilization. The Multicenter Study of Perioperative Ischemia Research Group. Ann Intern Med 1998; 128:194-203.

29. Chertow GM, Lazarus JM, Christiansen CL, Cook EF, Hammermeister KE, Grover F, et al. Preoperative renal risk stratification. Circulation 1997;95:878-84.

30. Kuitunen A, Vento A, Suojaranta-Ylinen R, Pettilä V. Acute renal failure after cardiac surgery: evaluation of the RIFLE classification. Ann Thorac Surg 2006;81:542-6.

31. DeFoe GR, Ross CS, Olmstead EM, Surgenor SD, Fillinger MP, Groom RC, et al. Lowest hematocrit on bypass and adverse outcomes associated with coronary artery bypass grafting. Northern New England Cardiovascular Disease Study Group. Ann Thorac Surg 2001;71:769-76.

32. Cook DJ, Proper JA, Orszulak TA, Daly RC, Oliver WC Jr. Effect of pump flow rate on cerebral blood flow during hypothermic cardiopulmonary bypass in adults. J Cardiothorac Vasc Anesth $1997 ; 11: 415-9$.

33. Slogoff S, Reul GJ, Keats AS, Curry GR, Crum ME, Elmquist $\mathrm{BA}$, et al. Role of perfusion pressure and flow in major organ 
dysfunction after cardiopulmonary bypass. Ann Thorac Surg 1990;50:911-8.

34. Bove T, Calabrò MG, Landoni G, Aletti G, Marino G, Crescenzi
$\mathrm{G}$, et al. The incidence and risk of acute renal failure after cardiac surgery. J Cardiothorac Vasc Anesth 2004;18:442-5. 